\title{
PRECIPITATING ANTIGENS OF THE NORMAL HUMAN PROSTATE
}

\author{
R. J. ABLIN, W. A. SOANES, P. BRONSON AND E. WITEBSKY†
}

Division of Immunology, Millard Fillmore Hospital, and Center for Immunology, School of Medicine, State University of New York at Buffalo, Buffalo, New York

\section{(Received 2nd January 1970)}

\begin{abstract}
Summary. Preliminary gel diffusion precipitation studies of rabbit antisera to saline extracts of pooled normal human prostatic tissue have demonstrated the presence of three prostate-specific antigens. Two of the antigens were found in prostatic tissue extract, and the third occurred in both prostatic tissue extract and prostatic fluid.
\end{abstract}

Several studies initiated in this laboratory have dealt with the immunological and immunochemical characterization of normal and pathological human prostatic fluid (Soanes, Gabrielli \& Felch, 1961; Shulman, Bronson, Gonder \& Soanes, 1963; Soanes, Shulman, Mamrod, Barnes \& Gonder, 1963; Barnes, Soanes, Gonder, Mamrod \& Shulman, 1963; Barnes, Shulman, Gonder \& Soanes, 1965). Stimulated by the possibility of pursuing similar studies on the human prostate gland, experiments were designed to define the antigenic constitution of the gland under normal, benign and malignant conditions through the production of antibodies by heteroimmunization with appropriate extract preparations.

This communication presents the results of preliminary studies of rabbit antibodies to normal human prostatic tissue as evaluated by double diffusion gel precipitation.

For the production of heteroimmune sera to antigens of normal human prostatic tissue, saline extracts prepared from pooled human prostate glands obtained at autopsy from a variety of clinical cases other than diseases of the prostate were emulsified with an equal volume of complete Freund's adjuvant and injected intradermally into each of four New Zealand rabbits (8 to $10 \mathrm{lb}$ ). Inoculations were repeated weekly for a period of 27 weeks. Trial bleedings were obtained weekly and were evaluated by double diffusion gel precipitation according to the method of Ouchterlony (1948).

Rabbit antisera to saline extracts of pooled normal human prostatic tissue (HPE) reacted in double diffusion gel precipitation tests with HPE, as well as with comparable extract preparations of other human tissues and fluids. Rigorous absorption of anti-HPE sera with freeze-dried saline extracts of other

* Present address: Immunology Section, Renal Unit, Memorial Hospital of Springfield, Springfield, Illinois 62701 .

$\dagger$ The Editor regrets to report that Dr E. Witebsky died on 7th December 1969. 
human tissues and fluids demonstrated that a portion of these antibodies were prostate specific. Two to three lines of precipitation were generally observed between absorbed anti-HPE sera and HPE. The specificity of the third line of precipitation, appearing as a rather diffuse band on, or adjacent to, the periphery of the antigen-containing well, was somewhat questionable. No precipitation was observed with normal human serum, nor with extracts of liver, heart, lung or kidney.

Subsequent evaluation of anti-HPE sera by gel diffusion precipitation with preparations of human prostatic fluid (HPF) and human seminal plasma (HSPl) revealed that two of the three lines of precipitation occurring between anti-HPE sera and HPE were specific for HPE, while the third was not specific for HPE but was specific for HPF. The reaction of HSPl with anti-HPE sera yielded a single line of precipitation which merged with the line of precipitation common to both HPE and HPF. It was suggested that this cross-reaction with HSPl was due to the fact that seminal plasma contains a certain amount of prostatic fluid, a contention which was verified by the fact that absorption of anti-HPE sera with HPF removed the line of precipitation occurring with HSPI. No other cross-reactions were observed between absorbed anti-HPE sera and extract preparations of other genital tissues, e.g. testis.

Studies of the nature of the species specificity of this prostate-specific antigen are in progress.

Specifically prepared heteroimmune sera to normal human prostate tissue, in addition to antisera to extracts of benign and malignant prostatic tissues are at present being used in an attempt to facilitate comparative studies of the antigenic constitution of these tissues through utilization of the combined specificity of antigen-antibody interaction in gel diffusion precipitation and enzymatic analysis (Pfeiffer, Ablin, Gonder \& Soanes, 1970).

Note added in proof. A more comprehensive report employing the methods of passive haemagglutination and immunoelectrophoresis has since appeared (Ablin, Bronson, Soanes \& Witebsky, 1970).

This research was supported by a grant from the John A. Hartford Foundation, Inc.

\section{REFERENCES}

Ablin, R. J., Bronson, P., Soanes, W. A. \& Witebsky, E. (1970) Tissue- and species-specific antigens of normal human prostatic tissue. $\mathcal{F}$. Immunol. 104 (in press).

Barnes, G. W., Soanes, W. A., Gonder, M. J., Mamrod, L. \& Shulman, S. (1963) Immunologic properties of human prostatic fluid. F. Lab. clin. Med. 61, 578.

Barnes, G. W., Shulman, S., Gonder, M. J. \& Soanes, W. A. (1965) Further studies of the immunological properties of human prostatic fluid. F. Lab. clin. Med. 66, 741 .

OUCHTERLONY, O. (1948) In vitro method for testing the toxin-producing capacity of diphtheria bacteria. Acta path. microbiol. scand. 25, 186.

Pfeiffer, L., Ablin, R. J., Gonder, M. J. \& Soanes, W. A. (1970) Antibodies to human prostatic acid phosphatase. Fert. Steril. 21, 344.

Shulman, S., Bronson, P., Gonder, M. J. \& Soanes, W. A. (1963) Ultracentrifugal constituents of human and canine prostatic fluid. Nature, Lond. 197, 58.

SoAnes, W. A., Gabrielli, E. \& FELCH, K. (1961) Biochemical classification of prostatitis: Based on electrophoretic study of prostatic fluid. 7. Urol. 85, 621 .

Soanes, W. A., Shulman, S., Mamrod, L., Barnes, G. W. \& Gonder, M. J. (1963) Electrophoretic analysis of prostatic fluid. Investve Urol. 1, 269. 